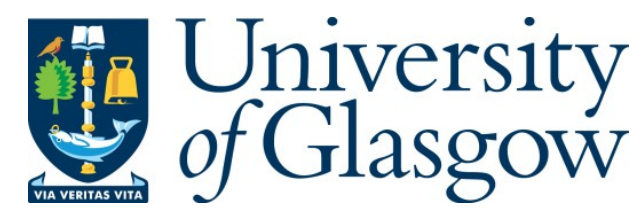

Padfield, Rory et al. (2014) Research agendas for the sustainable management of tropical peatland in Malaysia. Environmental

Conservation . pp. 1-11. ISSN 0376-8929

Copyright @ 2014 Cambridge University Press

A copy can be downloaded for personal non-commercial research or study, without prior permission or charge

Content must not be changed in any way or reproduced in any format or medium without the formal permission of the copyright holder(s)

When referring to this work, full bibliographic details must be given

http://eprints.gla.ac.uk/92219/

Deposited on: 05 M arch 2014

Enlighten - Research publications by members of the University of Glasgow http://eprints.gla.ac.uk 


\section{Research agendas for the sustainable management of tropical peatland in M alaysia}

RORY PADFIELD ${ }^{1} *$, SUSAN WALDRON ${ }^{2}$, SIMON DREW ${ }^{2}$, EFFIE PAPARGYROPOULOU ${ }^{1}$, SHASHI KUMARAN ${ }^{3}$, SUE PAGE ${ }^{4}$, DAVE GILVEAR ${ }^{5}$, ALONA ARMSTRONG $^{6}$, STEPHANIE EVER ${ }^{7}$, PAUL WILLIAMS ${ }^{7}$, ZURIATI ZAKARIA ${ }^{1}$, SING YUN CHIN ${ }^{8}$, SUNE HANSEN ${ }^{9}$, AHIM SA CAMPOSARCEIZ10, MOHD TALIB LATIF ${ }^{11}$, ALEX SAYOK ${ }^{12}$ AND MUN HOU THAM ${ }^{1}$

${ }^{1}$ M alaysia J apan International Institute for Technology, U niversiti Teknologi M alaysia, Kuala Lumpur 54100, Malaysia, ${ }^{2}$ School of G eographical and Earth Sciences, University of G lasgow, Glasgow G12 8Q Q , UK, ${ }^{3}$ Research Institute for Environment and Livelihoods, Charles D arwin University, Darwin NT 0909, Australia, ${ }^{4}$ D epartment of G eography, U niversity of Leicester, Leicester LE1 7RH, UK, ${ }^{5} \mathrm{~F}$ aculty of Science and Environment, Portland Square Building, D rake Circus, Plymouth PL4 8AA, UK, ${ }^{6}$ D epartment of Environmental Science, Lancaster Environment Centre, Lancaster U niversity, Lancaster LA1 4YQ, UK, ${ }^{7}$ School of Biosciences, U niversity of Nottingham Malaysia Campus, Semenyih, Selangor Darul Ehsan 43500, M alaysia, ${ }^{8} \mathrm{G}$ lobal Environment Centre, Petaling J aya, Selangor 47300, Malaysia, ${ }^{9}$ U TM Palm Oil, Universiti Teknologi Malaysia, Kuala Lumpur 54100, Malaysia, ${ }^{10}$ School of G eography, U niversity of Nottingham M alaysia Campus, Semenyih, Selangor Darul Ehsan 43500, Malaysia, ${ }^{11}$ School of Environmental and Natural Resource Sciences, F aculty of Science and Technology, U niversiti Kebangsaan Malaysia, 43600 Bangi, Selangor, M alaysia, and ${ }^{12}$ Institute of Biodiversity and Environmental Conservation, U niversiti Malaysia Sarawak, 94300 K ota Samarahan, Sarawak, M alaysia Date submitted: 5 A ugust 2013; Date accepted: 7 J anuary 2014

*Correspondence: Dr Rory Padfield Tel: +60 136632037 e-mail: rorypadfield@gmail.com

Running headers: $\quad$ Tropical peatland research agendas in M alaysia

R. Padfield et al. 


\section{SUM MARY}

There is a need for coordinated research for the sustainable management of topical peatland. M alaysia has $6 \%$ of global tropical peat by area and peatlands there are subject to land use change at an unprecedented rate. This paper describes a stakeholder engagement exercise that identified 95 priority research questions for peatland in M alaysia, organized into nine themes. A nalysis revealed the need for fundamental scientific research, with strong representation across the themes of environmental change, ecosystem services, and conversion, disturbance and degradation. Considerable uncertainty remains about $\mathrm{M}$ alaysia's baseline conditions for peatland, including questions over total remaining area of peatland, water table depths, soil characteristics, hydrological function, biogeochemical processes and ecology. M ore applied and multidisciplinary studies involving researchers from the social sciences are required. The future sustainability of M alaysian peatland relies on coordinating research agendas via a 'knowledge hub' of researchers, strengthening the role of peatlands in land-use planning and development processes, stricter policy enforcement, and bridging the divide between national and provincial governance. Integration of the economic value of peatlands into existing planning regimes is also a stakeholder priority. Finally, current research needs to be better communicated for the benefit of the research community, for improved societal understanding and to inform policy processes.

Keywords: M alaysia, research agendas, sustainable management, stakeholder engagement, tropical peatland

\section{INTRODUCTION}

There is growing international recognition of the important ecosystem services played by peatland environments, such as potable water supply (Rosli et al. 2010; Silvius \& Suryadiputra 2010), biodiversity (Page et al. 2012) and carbon storage (Billett et al. 2010; Page et al. 2011a, b; M oore et al. 2013). This increased recognition is reflected in a surge of policies and initiatives to maintain the integrity of peat across temperate and tropical peat zones. Initiatives such as the A ssociation of South East A sian Nations' (A SEAN) 
Peatland M anagement Strategy (A SEAN Secretariat 2007) and International Union for Conservation of Nature's (IUCN) Commission of Inquiry on Peatlands, UK (Bain et al. 2011), and country-wide policies such as the Scottish Soil Framew ork (Scottish Government 2009) and national greenhouse gas (GHG) emission reduction plans for Indonesian peat (IIPC [International Indonesian Peatland Conversation], unpublished data 2013) illustrate the intent of policy makers to address past perceptions and inappropriate peatland management practices. Despite this, the maintenance and status of the world's peatlands is a matter of considerable concern (W östen et al. 1997; Page et al. 2006, 2009a; Parish et al. 2008; Y ule 2010) with ongoing uncertainties on the most appropriate management practices and a lack of consensus over the best way forward.

To date, peatland research has strongly focused on boreal and temperate peats, with important knowledge developments in aspects such as peatland function and characteristics (see for example Heikurainen \& Päivänen, 1970; Hogg et al. 1992; Bonnett et al. 2006), and management techniques for restoration and rehabilitation (see K omulainen et al. 1998; Shantz \& Price 2006; W orrall et al. 2007). Research into tropical peat has generally lagged behind and, whilst this is changing (see M elling et al. 2005; Page et al. 2011b), substantial gaps in various aspects of fundamental knowledge remain. Past studies have highlighted the need for improved understanding of various aspects of the management and monitoring regime of tropical peatlands, such as practices that modify the water table and agricultural management techniques ((Wösten et al. 1997; Farmer et al. 2013).

Despite growing recognition of the differences between peat in different climatic regions, gaps in tropical peatland knowledge have often been filled with assumptions based on boreal and temperate peats (IPCC 2006; M urdiyarso et al. 2010; K oh et al. 2011). Inappropriate assumption setting for tropical peat was highlighted following the Intergovernmental Panel on Climate Change's (IPCC) development of guidelines for national GHG inventories (IPCC 2006). In particular, the assumed values for GHG emissions from different land uses on tropical peat were argued to be too low (C ouwenburg 2011). M isleading GHG emission values associated with peatland development have international implications, since GHG emissions make up an integral part of the evidence base for eligibility of 'sustainable agrofuels' under the European Union's Renewable Energy Directive (van Stappen et al. 2011). 
Thus, there is a need for a coordinated research agenda and a robust scientific evidence base to support national and international policies to assist towards the 'wise use approach' of tropical peatland (Page et al. 2006). A wise use approach involves evaluation of functions and uses, impacts caused by and constraints to development so that, by assessment, reasoning and consensus, it should be possible to highlight priorities for their management and use, including mitigation of past and future damage (Page et al. 2006). A move towards a wise use approach would al so support international initiatives such as the U nited Nation's Reducing Emissions from Deforestation and Forest Degradation (REDD; www.un-redd.org/) programme and the Roundtable for Sustainable Palm Oil (RSPO; http://www.rspo.org/). B oth of these initiatives require a strengthening of the evidence base for the monitoring and management of tropical peatland.

M alaysia has $6 \%$ of global tropical peat by area and $10 \%$ by magnitude of the peat carbon pool (Page et al. 2011b) and M alaysian peatlands are subject to land-use change at an unprecedented rate (SarV ision 2011; T suyuki et al. 2011). Over the past two decades, approximately $5861 \mathrm{~km}^{2}$ of $21306 \mathrm{~km}^{2}$ (or $27.5 \%$ ) of peatlands in M alaysia have been converted to agriculture, most notably for oil palm, and subjected to infrastructure development, posing direct negative impacts to peatland ecosystem and diversity (W etlands International 2010). Conversion is made worse by poor understanding of peatland soil characteristics (Y ule 2010).

W ith the aim of contributing towards a coordinated research agenda for the sustainable management of topical peatland, this paper captures a range of $M$ alaysian stakeholder perspectives to identify priority research questions going forward. Following a description of the methods used to gather stakeholder opinions, the priority research questions are listed and analysis undertaken of the cross-cutting themes, significant knowledge gaps, and different question types. The final section discusses what needs to be done to sustain M alaysia's peatlands and how research can support a path towards sustainable management of tropical peatland.

In this paper, sustainable management of tropical peatland is understood as a means to achieve 'sustainable development' (W orld Commission on Environment and Development 1987) through a wise use approach (Page et al. 2006, see above). We consider research that meets the needs of current and future peatland stakeholders, including those of government, non-governmental organizations, industry and other key 
agencies. By acknowledging the variety of needs and uses of peatlands to different stakeholders, but also the need for a wise use approach, we seek common research priorities rel evant to the current and future sustainability of Malaysian peatland.

\section{METHODS}

Our research process proceeded via a series of steps (Fig. 1). Interest amongst M alaysia's peatland stakeholders was generated in an initial Carbon Landscapes and Drainage (CLAD) knowledge exchange workshop held at Universiti Teknologi M alaysia (UTM ), K uala L umpur in M arch 2011. At this workshop, fifteen respondents completed a questionnaire and were asked to invite others to participate from their respective peatland networks, an approach used successfully in other stakeholder consultations (for example Brown et al. 2010). The respondents indicated their stakeholder group, and identified priority research questions within the following eight themes: scientific research and development, policy, knowledge exchange/information sharing, management and monitoring, conservation, economic and finance, national and regional cooperation, and other.

Fifty-one completed questionnaires were submitted between J une and September 2011 and included 250 research questions. Thirty-three participants from a variety of peatland stakeholders attended a second workshop at UTM (December 2011) in order to consolidate the research questions. However, this time participants were asked to work within the themes with which they were most comfortable. D rawing on Brown et al. (2010), participants were asked to combine similarly worded questions, identify and amal gamate questions with a similar underlying focus, reject questions that participants knew to have been researched al ready, and delete 'questions' that were merely comments or observations. This exercise led to the reorganization of the initial eight themes to nine themes, and the identification of 95 questions within these themes. The nine themes are: (1) environmental change; (2) ecosystems services; (3) conversion, disturbance and degradation; (4) policy and regulation; (5) knowledge exchange/communication; (6) management and monitoring; (7) conservation; (8) economic and financial planning; and (9) national and regional cooperation. 
W ith this clear sub-division of questions and themes, using an online survey tool (www.surveymonkey.com), stakeholders were asked to identify the top two priority questions from each of the nine themes. Participants were asked to identify two questions because the range of issues raised made it difficult for participants to identify just one priority question, whereas all owing two questions made the survey more engaging to participants. A gain, online participants were asked to identify their stakeholder group to allow determination of the level of agreement on questions across the different groups. Within each theme, we determined the prioritization score assigned by the stakeholders to each research question as a percentage; this per cent prioritization does not add to $100 \%$ as the respondents were allowed to identify the two highest priority questions within each of the nine themes.

Finally, we further categorized the list of 95 questions by 'question type', namely whether they related to scientific process and systems, communication, governance or systems management. Categorizing the list of questions in this way moved our analysis beyond a simple focus on priority topics and themes, enabling a more fundamental and encompassing view of the required line of research enquiry. Whilst 'scientific process and systems' was anticipated to be the primary research question type, assessing the fraction of non-scientific questions (for example concerning governance, communication, and systems management) offers a more comprehensive analysis of our findings, which in turn can support the direction of future research agendas in tropical peatland.

This research relied upon the participation of a relatively specialized knowledge group and access to unique networks within the context of M alaysian peatland. The 'snowball sampling' strategy (W right \& Stein 2005), whereby stakeholders extend the questionnaire to contacts in their respective networks, allowed a larger sample of potential respondents to be constructed from a small starting number. Generating support for this exercise in the initial CLAD-UTM workshop proved an important step in the research process.

\section{RESULTS}

We broke down the respondents by stakeholder type (Fig. 2) and organized the 95 research questions into the nine themes. Within each theme, questions were ranked according to their prioritization score. 


\section{Breakdown of survey respondents by stakeholder type}

A cademic stakeholders were the largest group to participate, representing $55 \%$ and $66 \%$ of total participants in the research questions survey and prioritization exercise, respectively. The second highest group to participate were non-governmental agencies (NGOs), who represented $18 \%$ and $11 \%$, respectively. The least represented group were private developers (research questions survey $2 \%$; prioritization survey $3 \%$ ), indicating the difficulty in reaching this stakeholder type in research surveys.

The relatively high number of respondents who contributed research questions and participated in the prioritization exercise suggests the identification of priorities for peatland research is an issue of interest to a wide range of stakeholders. Further, some of these stakeholders represented 'powerful and influential stakeholders', such as government agencies, private sector (such as agricultural developers) and national research institutes. In the context of tropical peatlands, and compared with other stakeholders participating in this study, these organizations have significant influence over issues such as land-use change, governance and management policy, and conservation and restoration efforts.

\section{Priority research questions by theme}

The 95 research priority questions are listed below by theme. The percentage of respondents who rated each question as a priority is indicated in brackets.

Environmental change

(1) What effect will the drivers of change have on the peatlands? In terms of water table depth, drought severity, flooding and fire? (40\%)

(2) What effect will the drivers of change have on gas emissions, fluvial fluxes, decomposition and subsidence rates? (32\%)

(3) How can total carbon storage be maintained or enhanced? (30\%) 
(4) What are the expected environmental drivers of change in $\mathrm{M}$ alaysia, including climate change and development pressures? (29\%)

(5) What is the total carbon storage in $M$ alaysia peatland and what are the best methods to measure it? $(29 \%)$

(6) What contribution do peatlands make to national carbon emissions and how can emissions be mitigated? (20\%)

(7) To what extent does dissolved organic carbon (DOC) and particulate organic carbon (POC) contribute to the total carbon losses from M alaysian peatland? (14\%)

E cosystem services

(1) How will peatland ecosystem services continue to be affected by drivers such as climate change, population increase, land use policies, and economic development? (38\%)

(2) What is the total area and condition of peatland in $M$ alaysia, where peatlands refer to all types including disturbed, pristine and protected? (36\%)

(3) How have the ecosystem services been affected by degradation and conversion of peatland and what values do they retain? (32\%)

(4) What are the effects of drainage and the role of the water table in ecosystem functioning in tropical peatland? (32\%)

(5) What are the impacts of peatland development on biodiversity? (27\%)

(6) What ecological variation exists between different peatland areas in M alaysia and what are the biogeographical factors influencing this variation? (21\%)

(7) How important are remnant peat swamp forests as habitats for endangered species such as orang utans and proboscis monkeys? $(21 \%)$

(8) What taxonomic species are unique to peat swamps versus tropical lowland dipterocarp and freshwater swamp forests? (14\%)

(9) What is the relationship between carbon dynamics and biodiversity in peat swamp forest? (14\%)

(10) Does the humic substance in peat affect the solubility of organic and inorganic components? (5\%) 
Conversion, disturbance and degradation

(1) What mitigation measures to rehabilitate degraded peatland are most suitable to M alaysia? What components of the ecosystem should be prioritized for rehabilitation: for example hydrology, vegetation cover, biodiversity? (61\%)

(2) What is the rate of peatland conversion from peatland swamp forest to other land uses? $(30 \%)$

(3) What are the macro- and micro-level socioeconomic impacts of converting and/or degrading peatland? (29\%)

(4) How sustainable are alternative land uses on peat swamp forest? (27\%)

(5) How resilient are the peat forests to disturbances, and which types of disturbance are the most devastating? (25\%)

(6) What are the effects of peatland disturbance on local and regional weather patterns? (21\%)

(7) What is the impact of drainage and rewetting on peat microbiology? (16\%)

(8) How to optimize the yield of oil palm planting on tropical peatland with minimum environmental impact? (14\%)

(9) What is the pattern of compaction and decomposition that occurs post-conversion of peat to agriculture? (13\%)

(10) How long can peatland be used (at various depths) before there are problems with (a) acidity, (b) lack of soil structural support, (c) nutrient levels? (13\%)

(11) What is the impact of fire on peat chemistry and microbiology? (11\%)

Policy and regulation

(1) How can peatland be wisely managed through effective implementation of the existing legal and policy framework and integration of the current land-use policies and plans? (47\%)

(2) What regulatory frameworks are required to support the management of peatland, and the conservation of key sites? (47\%) 
(3) How can the federal-state divide be bridged to effectively implement a national level policy or plan for peatland? (41\%)

(4) How can policy respond more effectively to peatland research? (28\%)

(5) How can national peatland policy help the country to conserve and progress simultaneously? How can this policy be properly enforced? $(26 \%)$

(6) How can carbon sequestration be effectively dealt with through the new national policy on climate change and mitigation? (22\%)

Knowledge exchange/communication

(1) How can current scientific knowledge be synthesized and translated into policy-relevant information to aid policy and decision-making, management and to suggest further research? (38\%)

(2) How can the public be made aware of peatland degradation and its effects? (36\%)

(3) Should a M alaysian peatland working group/research group be established to facilitate knowledge exchange in a neutral and balanced environment? $(28 \%)$

(4) How can we enhance the collaboration between universities, industries, government agencies and NGOs in tackling issues related to peatland? (26\%)

(5) What are the specific needs of the different stakeholders and how can policy help to promote multistakeholder participation? (24\%)

(6) Tropical peat is different from temperate peat. M ost assumptions are based on temperate peat research causing problems to the tropical peat developers. How can this perspective of tropical peat be changed? (24\%)

(7) How can the economic and ecological values of peatland, including its function as carbon stores, be more effectively promoted to the public? (20\%)

(8) How can the locals in regions of oil palm development be educated about sustainable peatland management and alternative uses for peat? $(20 \%)$

(9) How effective are the existing mechanisms for knowledge exchange for the public and how can they be improved? (14\%) 
(10) What potential and how appropriate is it to use expertise from temperate peat zones? (8\%)

(11) Should an information sharing centre be created to advise policy and decision-making? (6\%)

Management and monitoring

(1) Have existing management plans for conservation and restoration of peatland been successful and how can current monitoring systems be improved? $(28 \%)$

(2) How can peat forest rehabilitation be managed within a multidimensional framework, including water management, reforestation and al ternative livelihoods? (25\%)

(3) What techniques can be used to conduct low-cost monitoring? (23\%)

(4) What role can the local communities play in managing and monitoring peatland? (23\%)

(5) How can change be brought about to align stakeholders towards a common vision for sustainable peatland management that is of long-term value for the nation and maintains global environmental benefits? (23\%)

(6) What are key factors for monitoring M alaysian peatland and determining its conditions? (21\%)

(7) How can a long-term permanent monitoring network for peatland be established? (19\%)

(8) What are the most sustainable management practices for oil palm and biofuel production on peatland? $(18 \%)$

(9) How effectively do monitoring results inform management decision-making? (18\%)

(10) What role can REDD play in maintaining and restoring peatland in M alaysia? (14\%)

(11) How can agencies in peatland management be effective in ensuring that management and monitoring plans are sustainable in terms of technical capacity, financial resources and institutional collaborative arrangements? (14\%)

(12) How do we ensure that managers of cultivated peat areas are familiar with best practices and conduct proper monitoring? (14\%)

(13) What actions are required to rehabilitate and restore the peatland forests? (14\%)

(14) How are local communities involved, if at all, in the decision-making process about the management, conversion and development of peatland areas? (14\%) 
(15) How have the findings from past research programmes been integrated into management plans? $(14 \%)$

(16) How can a comanagement approach be applied to M alaysian peatland? (12\%)

(17) What are the weaknesses and conflicts of interest between individual institutions within $M$ alaysia with regard to sustainable management? (11\%)

(18) W hat is the level of influence of different stakeholders (at the federal, state and the community level) related to peatland management and what are the relationships between different stakeholders? (9\%)

(19) How and what might be the benefits of using the RSPO to promote sustainable peatland management? $(5 \%)$

Conservation

(1) What are the possible conservation strategies that can be adopted to conserve peatland? (55\%)

(2) How can we prioritize conservation and make it reflect the true value in terms of economic development? (40\%)

(3) What are the best management practices for peat conservation, in terms of water table maintenance? $(36 \%)$

(4) A re current conservation measures adequate? If not, how can they be improved? (30\%)

(5) What can M alaysia learn from other countries in terms of peatland conservation? (28\%)

(6) What are the long-term goals for conservation measures? (26\%)

Economic and financial planning

(1) How do we ensure that information on the true economic value of peatland is considered in decisionmaking (for example through environmental impact assessment) related to the conversion of peatland areas? (41\%)

(2) What is the total economic value of $M$ alaysian peatland and how can this be measured? (39\%)

(3) W hat are the real costs of not taking account of the economic values of peatland and who bears these costs? (33\%) 
(4) How can the revenue from the economic development of peatland be channelled to support sustainable peatland management practices? $(28 \%)$

(5) Can M alaysia undertake a national ecosystem assessment similar to that which has just been completed and published in the UK? (26\%)

(6) How can private sector investment in peatland restoration be achieved? (24\%)

(7) Can voluntary and market-driven instruments such as carbon trading and certification schemes be effective in sustainable management and conservation of peat? (22\%)

(8) What can the government do to promote tourism and recreation on peatland? (22\%)

(9) How can environmental economic instruments (such as tax, user payments and land premiums) be best used for the sustainable management of peatland? (20\%)

(10) How does the revenue from extractive uses compare with REDD + and the voluntary carbon markets? $(16 \%)$

(11) W hat are initial estimates for potential carbon finance revenues for conservation of tropical peat forests? (14\%)

National and regional cooperation

(1) How can M alaysia be more accountable for adhering to international/ regional standards in relation to peatland? (35\%)

(2) How can implementation of regional agreements (for example the A SEA N Peatland M anagement Strategy) be strengthened at a national level? (28\%)

(3) Should ASEAN have a greater role in environmental regulations in the region? If so, how? (28\%)

(4) How can the participation of state governments and local communities be improved to preserve peatland? (28\%)

(5) How can regional cooperation be encouraged, specifically with regard to tropical peat swamp forest protection? $(26 \%)$

(6) What role can M alaysia play in regional initiatives for research on tropical peat swamp forest? (22\%) 
(7) How can regional initiatives contribute towards solving the regional haze problem that results from the burning of peat? $(22 \%)$

(8) How can the cooperation between $\mathrm{M}$ alaysia and Indonesia be strengthened in order to further the sustainable management of peatland? (22\%)

(9) How would a regional network of collaborative research on peatland be established and function effectively? (20\%)

(10) How can a dedicated monitoring body or agency regulate the management of peatland in A SEA N ? $(20 \%)$

(11) A re regionally-focused, as opposed to nationally-focused initiatives more likely to lead to sustainable management of peat in M alaysia? (18\%)

(12) How can it be ensured that research and experiences from other countries in- and outside the region are included in the research and assessed in the ASEAN region? (14\%)

(13) Would sharing custodianship with other countries help protect larger tracts of peat forest? (12\%)

(14) Should carbon loss from peatland be measured on a regional or national scale? (10\%)

\section{DISCUSSION}

\section{E merging and cross-cutting themes}

The need for fundamental research across a broad range of topics is illustrated by an analysis of the crosscutting themes that emerged from the categorization of question types (Fig. 3). The most common question type was 'scientific process and understanding', and the majority of these questions were spread across the themes of environmental change, ecosystem services provision, and conversion, disturbance and degradation. In contrast to temperate climates, where there is a strong tradition of funded research into fundamental science, considerable uncertainty remains about M alaysia's baseline conditions for peatland. Total remaining area of peatland, water table depths, soil characteristics, hydrological function and processes, ecology, and peatland catchment water chemistry are all examples of the lines of enquiry that require further research. 
Furthermore, as demonstrated by question (6) within the theme of knowledge exchange/communication ('Tropical peat is different from temperate peat. M ost assumptions are based on temperate peat research causing problems to the tropical peat developers. How can this perspective of tropical peat be changed?' ), there is agreed ambiguity over the comparisons that can be drawn between temperate and tropical peatland environments. This question reinforces the need for fundamental science studies in M alaysia and the associated development of local expertise to support such research.

The second most common question type was 'systems management' which featured across six of the nine themes, including a high proportion from the management and monitoring theme. The high number of 'systems management' questions indicates a need for research into more applied areas, involving multidisciplinary approaches and a scope beyond pure fundamental science. The next most frequent research questions were on 'governance', which suggests there is need for further socioeconomic research, policy studies and understanding of and integrating stakeholder needs into the policy process. The threats from agriculture, notably oil palm expansion, remain a major challenge in the drive towards sustainable management of tropical peatland. Finding a solution requires appropriate stakeholder engagement, especially in terms of the local communities and the decision makers, to understand the needs and demands of society with regard to peatlands; research that can attempt to find a harmony between development needs and conservation, protection and rehabilitation will therefore constitute an important element of the research framework going forward.

There is the need to better understand how peatland and associated ecosystems are affected by environmental change. Environmental change refers to the disturbance of natural ecological processes (J ohnson et al. 1997) and poses direct and significant impacts upon tropical peatland. For example, changes in critical climatic factors, such as temperature and precipitation can lead to reductions in the carbon store, disrupt the natural greenhouse gas flux, and are associated with increased incidence of peat fires (Page et al. 2009b) and reductions in biodiversity (Parish et al. 2008; Y ule 2010).

Research questions classified as 'communication' were the least represented but feature across five different research themes. The low relative prioritization of this class of question suggests poor recognition by respondents of the need to communicate scientific findings to stakeholder groups. This may have been a 
reflection of the academia-centric demographic of respondents; with greater prioritization given to fundamental research themes. While communication of issues is both a fundamental challenge and potentially misleading without greater understanding of the current baseline, development of both must go hand-in-hand to support further options or approaches towards sustainable management of peatland.

\section{A path towards sustainable management of tropical peat}

So what needs to be done to sustain M alaysia's peatlands, how can research assist to this end, and how does research inform understanding of the challenges? The present exercise was driven by an objective to better understand the priorities for peatland research in M alaysia as determined by peatland stakeholders, with a view of realizing a path towards sustainable management of $M$ alaysia's peatlands. There is a desired outcome for sustainable management of peatlands amongst participating stakeholders; however, this probably reflects the perceptions of a minority group and should not be interpreted as indicative of the views and perceptions of the wider M alaysian public.

Thus, a starting point would be to formulate a communication strategy to enhance the public profile of peatlands with a view of improving awareness to all related stakeholders, including industry (such as land developers), governmental, non-governmental, academia, consultants and the public. Recent research has stressed the importance of (re)framing specific issues or complex problems for public engagement in order to break through communication barriers and generate new ways of thinking (Lakoff 2010). Examples include western media framing of climate change policies (B oykoff \& B oykoff 2007), non-governmental frames for action against poverty in developing countries ( $M$ anzo 2008) and governmental framing of nuclear energy (Nisbet 2009).

Communication of scientific findings to aid the policy process is regarded as an important issue as demonstrated by the high priority given to question (1) under the theme of knowledge exchange/communication: 'How can current scientific knowledge be synthesized and translated into policyrelevant information to aid policy and decision-making, management, and to suggest further research?' This point was reaffirmed by stakeholders participating in both workshops with emphasis placed on the need to 
improve current communication strategies of past and current peatland research and provide more general publicly-available information related to the societal and ecological importance of peatland environments. The academic, governmental and non-governmental communities should take responsibility for considering and implementing effective public debate about tropical peatland. This could be realized through more coordinated research amongst the research institutions, better use of social media to promote and create public dialogue on critical issues, multi-stakeholder activities such as field visits, and active public engagement with governmental agencies to positively influence the policy process.

A $n$ improved communication strategy is especially pertinent when considering the challenges facing the integration of peatlands into the present policy process. The high priority for the three most highly ranked questions under the theme of policy and regulation indicates that strengthening the role of peatlands in landuse planning and development processes, stricter policy enforcement, coordination of existing policies, and bridging the state and federal divide are all critical aspects that need addressing. In support of a communication strategy, greater emphasis should be placed on research into the social sciences, such as economics, politics, sociology, geography, and town and country planning; disciplines not traditionally associated with peatlands research. Page et al. (2006) have previously called for improved knowledge of the socioeconomic, sociocultural and socioecological aspects of tropical peatland ecosystems.

We further recommend integration of the economic value of peatlands into existing planning regimes. In line with the definition of sustainable development that incorporates economic aspects, as well as environmental and social aspects (Glavic \& Lukman 2008; Rawlins \& M orris 2010), stakeholders identified the appropriate valuation of peatlands as a priority research issue (as indicated by the high percentage value of three most highly ranked questions under the theme economic and financial planning). Despite research into the economic value of some of M alaysia's peatlands (A wang 2006), such valuation is not current practice and so will require the development of a set of valuation metrics of peatlands, as well as the necessary steps for convergence into the policy process.

Supporting existing policies and initiatives by government agencies and NGOs working in this field is another aspect for consideration. NGOs such as W etlands International), M alaysia Nature Society and the Global Environment Centre, and specific projects such as SEA peat and the ASEA N Peat Forest Project 
(APFP; http://www .aseanpeat.net/) provide a platform for current initiatives and activities. Government interventions such as the designation of a RA M SAR peatland sites in East M alaysia, the establishment of the National A ction Plan of Peatlands (NRE [M inistry of Natural Resources and Environment] 2011) and the review of the National W etlands Policy (M OSTI [M inistry of Science, Technology and Environment] 2004) illustrate a statement of political will and action towards this objective. Offering ways to support these actions, including targeted research programmes, would be one approach.

In support of the efforts of the existing research institutions working in this topic area, a comprehensive and coordinated programme of research could be established. This could build on the priority research questions and themes identified in this paper whilst al so complimenting any existing frameworks for research overlooked in this research exercise. M oreover, considering the wider societal interests in peatlands (such as agriculture and tourism), opportunities for university-industry-government collaborations could be explored. University-industry collaborations are a growing area of interest in M alaysia as highlighted by recent research examining such partnerships in the M alaysian water industry (Padfield et al. 2014).

Building on the existing networks within the Malaysian peat community, it is proposed that a network or 'knowledge hub' of researchers be strengthened to coordinate efforts and seek strong proposals with higher chances of funding. This type of research requires a combination of different skill sets and disciplines, including natural scientists, sociologists, engineers, geographers and planners. A s Carmenta et al. (2011) advocated in relation to research into tropical peat fires 'interdisciplinary research designs are needed to improve current understanding and inform sustainable management solutions'. The network should also consider the means to communicate the findings from their research in a way that allows for greater policy convergence. Ideally, the network should extend beyond $M$ alaysia to help disseminate research findings and so share knowledge of tropical peat systematics and management. Furthermore, the network could serve to coordinate research related activities across countries in the ASEAN region and other areas of tropical peat globally.

\section{Limitations}


Canvassing opinions of stakeholders as undertaken in this research exercise is not without its limitations. Firstly, it is unlikely that all stakeholder opinions have been captured, whether due to the difficulty of reaching specific groups or because of a deliberate choice made by some not to participate in the exercise. Whilst efforts were made to reach out to less represented stakeholder groups (such as private developers and government agencies), the exercise clearly faced a challenge to engage with these groups. Despite this, it is encouraging that a range of stakeholders did participate in the surveys and workshop activities. It is also possible that some stakeholders took a more personal view about priority questions as opposed to representing the views of their organization. From the survey it is not clear which position respondents adopted and whether that would affect the outcome of the research process.

Secondly, due to the snowballing strategy employed in this research, the exact stakeholder reach of the questionnaire and prioritization exercise is unknown. It is possible that both surveys were distributed to a large number of stakeholders across many organizations and countries and yet, as stated above, many chose not to participate for their own reasons. However, identification of respondent's affiliations from the research questions survey indicated that from the 51 original respondents, only three organizations were represented by more than one respondent, with none contributing more than three individuals. Further, from analysis of those stakeholders who did participate in the surveys, there does not appear to be any bias within the surveys towards a specific research theme, viewpoint or agenda of individual organizations. Individual affiliations were not identified from respondents in the prioritisation exercise. However it was requested that participants reflect the extended network of the original survey respondents and not just immediate colleagues.

Thirdly, a further limitation relates to the format of the initial questionnaire used to generate the research questions. Respondents were requested to identify priority research questions within nine themes which, in turn, may have prevented questions being considered from outside of these themes. However, identifying pre-determined themes was deemed necessary to guide respondents across a broad range of issues which they may not have ordinarily considered. Finally, we recognize that during the consolidation workshop, the rewording of questions may have led to a loss of original meaning.

\section{CONCLUSIONS}


This paper presents a list of 95 research questions relevant for the study of tropical peatland and ranks them according to the priority ascribed to them by stakeholders via an online survey. W e find three main conclusions. Firstly, the comparatively limited knowledge of tropical peat as compared with boreal and temperate peat has led to inappropriate characterization of tropical peatland environments; unrepresentative understanding needs to be addressed by developing an appropriate evidence base through a more comprehensive programme of fundamental research which, in turn, requires greater support from funding agencies. Secondly, research needs to be better communicated, not just for the benefit of the research community, but to educate the public for improved societal understanding and to inform the policy process. Finally, this exercise has revealed the need for research into topics less commonly associated with peatland science, notably social science and non-technical aspects, to improve understanding on issues such as stakeholder needs and knowledge, policy and legal processes, and national and international governance issues. Consideration of all these issues may lead to improvements in the sustainable management of tropical peatland.

\section{ACKNOWLEDGEMENTS}

We acknowledge the UK Natural Environment Research Council (NERC NE/G 00885X/1) for funding Simon Drew, Susan Waldron and Dave Gilvear to run workshops in M alaysia, the Royal Society International Travel Grant scheme, the UK -A SEAN K nowledge Partnership M obility Scheme, and the UK Global Partnership Fund via the B ritish High Commission in K uala L umpur for funding A lona A rmstrong, Rory Walsh and Simon Drew. We acknowledge the contribution of M s Lee Ching Heong from the UK Science and Innovation Network. A special thank you to the respondents who participated in the survey and prioritization exercise, not all of whom felt they could be co-authors of this manuscript.

\section{References}


A SEA N Secretariat (2007) A SEA N Peatland M anagement Strategy 2006. $16^{\text {th }}$ A SEA N M inisterial M eeting on the Environment (AM M E), $10^{\text {th }}$ N ovember 2006, Cibu, Phillipines [www document]. URL http://haze.asean.org/docs/1245724927/A PM S_whole.pdf/view

A wang, A . (2006) E conomic valuation of forest ecosystem services in M alaysia. Faculty of Forestry, University Putra M alaysia, M alaysia [www document]. URL http://www.jst.go.jp/asts/asts_m/files/0311pdf/09_Seminar_ASTS_Penang_1014_March_2006_A wang_Noor.pdf

Bain, C.G., B onn, A ., Stoneman, R., Chapman, S., Coupar, A., Evans, M ., Gearey, B., Howat, M ., J oosten, H., Keenleyside, C., Labadz, J., Lindsay, R., Littlewood, N., L unt, P., M iller, C.J ., M oxey, A., Orr, H., Reed, M ., Smith, P., Swales, V ., Thompson, D.B .A ., Thompson, P.S., van de N oort, R., W ilson, J.D. \& Worrall, F. (2011) IUCN UK Commission of Inquiry on Peatlands. IUCN UK Peatland Programme, Edinburgh, UK [www document]. URL http://www.iucnukpeatlandprogramme.org/commission/findings Billett, M.F., Charman, D.J . Clark, J.M . Evans, C.D. Evans, M .G. Ostle, N.J, W orrall, F. B urden, A. Dinsmore, K.J. J ones, T. M cNamara, N.P. Parry, L. Rowson, J.G. \& Rose, R. (2010) Carbon balance of UK peatlands: current state of knowledge and future research challenges. Climate Research 45: 1329.

Bonnett, S., Ostle, N. \& Freeman, C. (2006) Seasonal variations in decomposition processes in a valleybottom riparian peatland. Science of the Total Environment 370(2): 561-573.

B oykoff, M . \& Boykoff, J. (2007) Climate change and journalistic norms: a case study of US mass-media coverage. Geoforum 38: 1190-1204.

Brown, L., M itchell, G., Holden, J., Folkard, A ., W right, N ., B eharry-Borg, N., B erry, G., B rierley, B ., Chapman, P., Clarke, S.J ., Cotton, L., D obson, M ., D ollar, E., Fletcher, M ., Foster, J., Hanlon, A., Hildon, P., Hiley, P., Hillis, P., Hoseason, J., J ohnston, K ., Kay, P., M cD onald, A., Parrott, A., Powell, A., Slack, R.J ., Sleight, A ., Spray, C., Tapley, K., U nderhill, R. \& W oulds, C. (2010) Priority water research questions as determined by UK practitioners and policy makers. Science of the Total Environment 409: 256-66. 
Carmenta, R., Parry, L., B lackburn, A., V ermeylen, S. \& Barlow. J (2011) Understanding human-fire interactions in tropical forest regions: a case for interdisciplinary research across the natural and social sciences. E cology and Society 16(1): 53.

Couwenberg, J. (2011) Greenhouse gas emissions from the managed peat soils: is the IPCC reporting guidance realistic? Mires and Peat 8(2): 1-10.

Farmer, J., M atthews, R., Smith, P.\& Smith, U. (2013) The tropical peatland plantation-carbon assessment tool: estimating $\mathrm{CO}_{2}$ emissions from tropical peat soils under plantations. Mitigation and Adaptation Strategies for G lobal Change [www document] URL http://link.springer.com/article/10.1007/s11027013-9517-4\#page-2

Glavi •, P. \& L ukman, R. (2008) Review of sustainability terms and their definitions. J ournal of Cleaner Production 15 (18): 1875-85.

Hogg, E., Lieffers, V . \& W ein, R. (1992) Potential carbon losses from peat profiles: effects of temperature, drought cycles, and fire. Ecological Applications 2(3): 298-306.

IPCC (2006) 2006 IPCC guidelines for national greenhouse gas inventories. National Greenhouse Gas Inventories Programme Report, ed. H. Eggleston, L. Buendia, K. M iwa, T. N gara \& K. Tanabe. IGES, Hayama, Japan [www document]. URL http://www.ipcc-nggip.iges.or.jp/public/2006gl/index.html

J ohnson, D., A mbrose, S., B assett, T., Bowen M., Crummey, D., Isaacson, J., J ohnson, D., L amb, P., Saul, M . \& W inter-N elson, A . (1997) M eanings of environmental terms. J ournal of Environmental Q uality 26(3): 581-589.

K oh, L., M iettinen, J., Liew, S. \& Ghazoul, J. (2011) Remotely sensed evidence of tropical peatland conversion to oil palm. Proceedings of the National Academy of Scientists USA 108: 5127-5132.

K omulainen, V., N ykänen, H., M artikainen, P. \& Laine, J . (1998) Short-term effect of restoration on vegetation change and methane emissions from peatlands drained for forestry in southern Finland. Canadian J ournal F orest Research 28: 402-411.

Heikurainen, L. \& Päivänen. J. (1970) The effect of thinning, clear cutting, and fertilization on the hydrology of peatland drained for forestry. Acta F orestalia F ennica 104: 1-23. 
Lakoff, G. (2010) Why it matters how we frame the environment. Environmental Communication: A J ournal of Nature and Culture 4(1): 70-81.

M anzo, K. (2008) I maging humanitarianism: NGO identity and the iconography of childhood. Antipode 40(4): 632-657.

M elling, L., Hatano, R. \& Goh, K . (2005) M ethane fluxes from three ecosystems in tropical peatland of Sarawak, M alaysia. Soil Biology and Biochemistry 37(8): 1445-1453.

M oore, S., Evans, C., Page, S., Garnett, M ., J ones, T., Freeman, C., H ooijer, A. W iltshire, A ., Limin, S. \& Gauci, V . (2013) Deep instability of deforested tropical peatlands revealed by fluvial organic carbon fluxes. Nature 493: 660-663.

M OSTI (2004) National W etlands Policy. Government of M alaysia. Putrajaya, M alaysia.

M urdiyarso, D., Hergoualc' h, K . \& V erchot, L. (2010) Opportunities for reducing greenhouse gas emissions in tropical peatlands. Proceedings of the National Academy Science USA 107: 19655-19660.

Nisbet, M . (2009) Communicating climate change: why frames matter for public engagement. Environment: Science and Policy for Sustainable Development 51(2): 12-23.

NRE (2011) National A ction Plan for Peatland. Government of M alaysia. Putrajaya, M alaysia.

Padfield, R., Richards, C., Y usop, Z., Parkey, J., Harrison, 0 \& Preece, C. (2014) Tackling wicked problems in the M alaysian water industry: a framework for university-industry research partnerships. J ournal of Governance and D evelopment (in press).

Page, S., Hooijer, A ., Rieley, J ., B anks, C. \& Hoscilo, A . (2012) The tropical peat swamps of Southeast A sia: human impacts on biodiversity, hydrology and carbon dynamics. Systematics Association 82: 406433.

Page, S., Hoscilo, A., Langner, A., Tansey, K., Siegert, F., Limin, S. \& Rieley, J. (2009b) Tropical peatland fires in Southeast A sia. In: Tropical Fire Ecology, ed. E. Johnson \& K. M iyanish, pp. 263-87. Berlin, Germany: Springer Praxis.

Page, S., Hoscilo, A., W östen, H., J auhiainen, J ., Silvius, M ., Rieley, J ., Ritzema, H., Tansey, K ., Graham, L., Vasander, H. \& Limin, S. (2009a) Ecological restoration of tropical peatlands in Southeast A sia. E cosystems 12: 888-905. 
Page, S., M orrison, R., M alins, C., Hooijer, A., Rieley, J . \& J auhiainen, J. (2011a) R eview of peat surface greenhouse gas emissions from oil palm plantations. In: Southeast A sia. W hite Paper N umber 15, September 2011. Indirect Effects of Biofuel Production Series. International Council on Clean Transportation. W ashington DC, USA .

Page, S., Rieley, J . \& Banks, C. (2011b) Global and regional importance of the tropical peatland carbon pool. Global Change Biology 17: 798-818

Page, S., Rieley, J. \& W üst, R. (2006) Chapter 7: L owland tropical peatlands of Southeast A sia. D evelopments in Earth Surface Processes 9: 145-72.

Parish, F., Sirin, A ., Charman, D., J oosten, H., M inayeva, T., Silvius, M . \& Stringer, L. (2008) A ssessment on peatlands, biodiversity and climate change: main report. G lobal Environment Centre, K uala L umpur, $M$ alaysia and W etlands International, W ageningen, the $N$ etherlands.

Rawlins, A . \& M orris, J. (2010) Social and economic aspects of peatland management in Northern Europe, with particular reference to the English case. Geoderma 154(3-4): 242-251.

Rosli, N., Gandaseca, S. Ismail, J . \& I qbal, J . (2010) Compartice study of water quality at different peat swamp forest of Batang Igan, Subu Sarawak. American J ournal of E nvironmental Science 6(5): 416421.

SarV ision (2011) Impact of oil palm plantations on peatland conversion in Sarawak 2005-2010. Report. W etland International, W ageningen, the N etherlands.

Scottish Government (2009) Scottish Soil Framework. The Scottish Government, Edinburgh, UK [www document]. URL http://www.scotland.gov.uk/Resource/D oc/273170/0081576.pdf

Shantz, M . \& Price, J . (2006) Hydrological changes following restoration of the Bois-des-Bel Peatland, Quebec, 1999-2002. J ournal of H ydrology 331(15): 543-553.

Silvius, J . \& Suryadiputra, N . (2010) Review of policies and practices in tropical peat swamp forest management in Indonesia. Report. W etlands International, W ageningen, the N etherlands [www document]. URL http://portals.wdi.wur.nl/files/docs/File/wffae/ReviewPoliciesPracticesPeatswampM anagement.pdf 
Tsuyuki, S., Goh, M ., Teo, S., Kamlun, K . \& Phua, M . (2011) M onitoring deforestation in Sarawak, M alaysia using multitemporal L andsat data. Kanto F orest Research 62: 87-90.

van Stappen, F., B rose, I. \& Schenkel, Y . (2011) Direct and indirect land use changes issues in European sustainability initiatives: state-of-the-art, open issues and future developments. Biomass and Bioenergy 35(12): 4824-4834.

W etlands International (2010) A quick scan of peatlands in M alaysia. Report. Petaling J aya, M alaysia [www document]. URL

http://malaysia.wetlands.org/Library/tabid/519/mod/1570/articleT ype/A rticleV iew/articleld/2675/A Quick-Scan-of-Peatlands-in-M alaysia.aspx

W orld Commission on Environment and Development (1987) 0 ur Common F uture. Oxford, UK : Oxford University Press.

W orrall, F., A rmstrong, A . \& Holden, J . (2007) Short-term impact of peat drain-blocking on water colour, dissolved organic carbon concentration, and water table depth. J ournal of H ydrology 337 (3-4): $315-$ 325.

Wösten, J., Ismail, A \& \& Wijk, A. (1997) Peat subsidence and its practical implications: a case study in M alaysia. G eoderma 78: 25-36.

W right, R. \& Stein, M (2005) Snowball sampling. In: The Encyclopedia of Social M easurement, ed. K. Kempf-Leonard, pp. 495-500. San Diego, CA, USA : Elsevier.

Y ule, C. (2010) L oss of biodiversity and ecosystem functioning in Indo-M alayan peat swamp forest. Biodiversity Conservation 19: 393-409. 


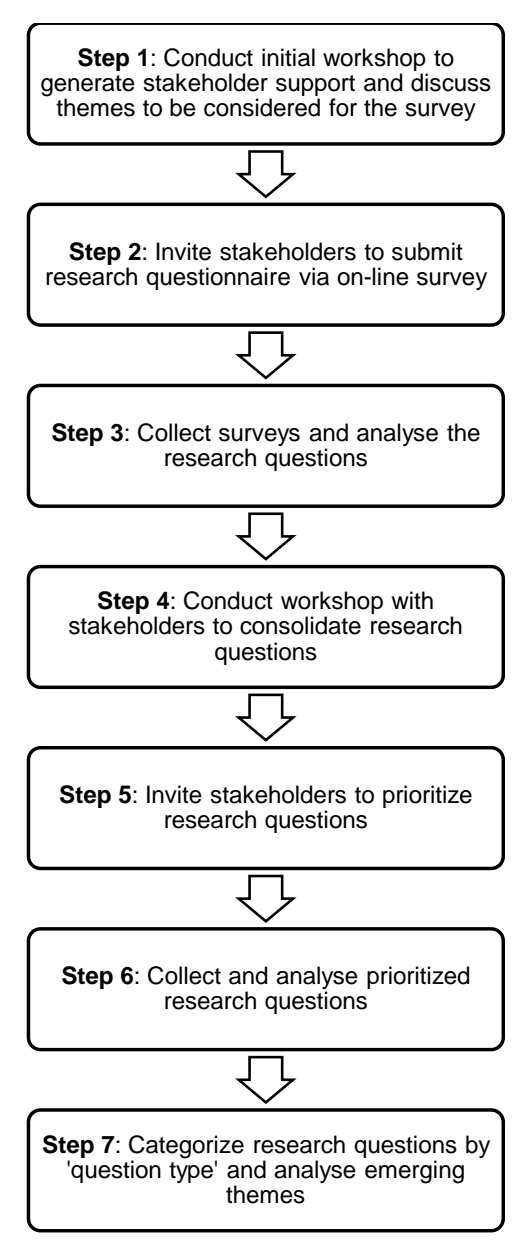

Figure 1 W orkflow of steps taken to generate, prioritize and analyse research questions 
(a)

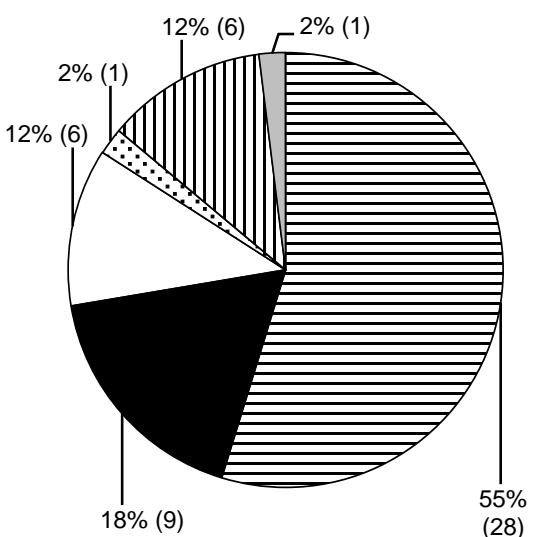

(b)

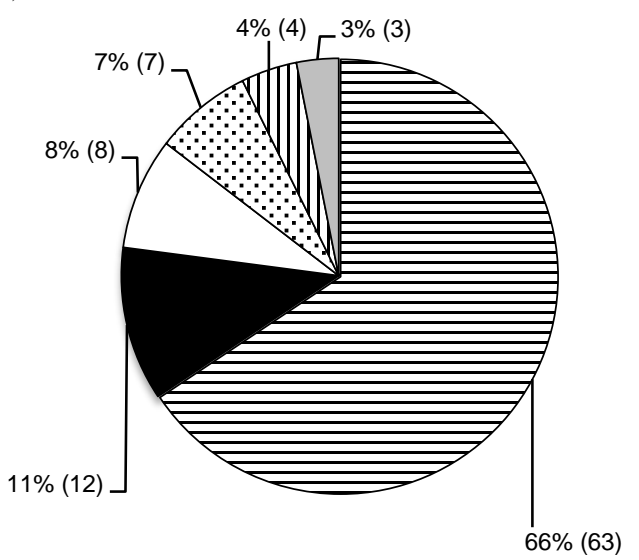

$\boxminus$ Academia

- NGO

$\square$ Government agencies

$\square$ Other

mConsultant

Figure 2 B reakdown of survey respondents by affiliation: (a) research questions survey ( $\%$ and number of respondents) (b) prioritization of research questions (\% and number of respondents). 


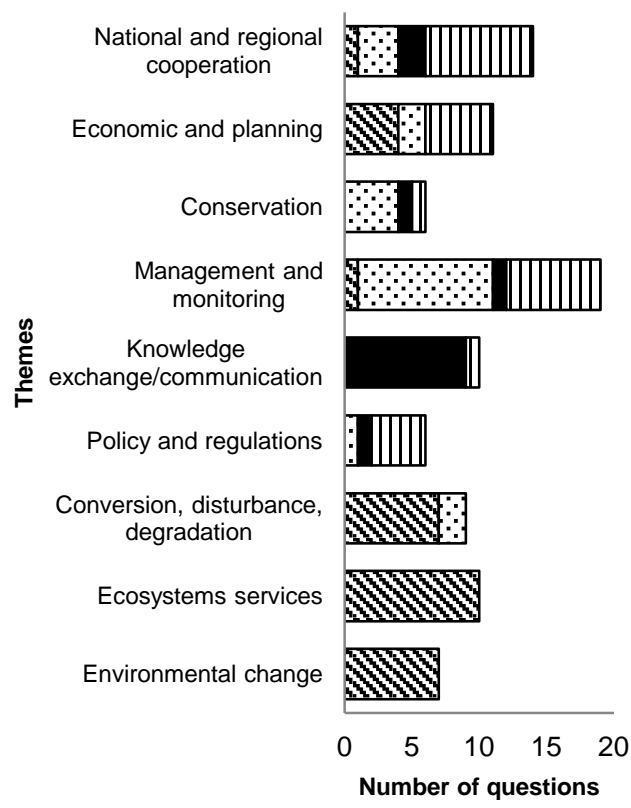

S S cientific processes and systems

$\square$ Systems management

-Communication

םGovernance

Figure 3 R esearch questions categorized by question type. 